Grace, J. B. (1954). J. gen. Microbiol. 10, 325-327

\title{
Some Observations on the Flagella and Blepharoplasts of Spirillum and Vibrio spp.
}

\author{
BY JOYCE B. GRACE \\ Department of Bacteriology, University of Birmingham
}

SUMMARY: The flagella of certain large spirilla appear to be compound structures composed of a large number of individual fibres. These arise in bundles from a single blepharoplast, whereas in other bacteria each flagellum arises separately. The flagella of spirilla are thus, in some respects, intermediate between those of other bacteria and of flagellates.

Since the description of a 'thread-like trunk' on cells of Ophidomonas (Thiospirillum) spp. which behaved as an organ of propulsion (Ehrenberg, 1838) numerous observations have been made on the flagella of both living and stained cells of large spirilla (Bütschli, 1902; Ellis, 1902; Fuhrmann, 1909; Reichert, 1909; Buder, 1915; Yuasa, 1936; Pijper, 1949). These have confirmed that most spirilla possess a large number of very fine flagellar strands, but have not adequately differentiated these complex structures from the multiple, lophotrichous flagella of, for example, Pseudomonas spp. Several workers (Bütschli, 1902; Fuhrmann, 1909; Yuasa, 1936) suggested that the flagella arose from a single basal structure analogous to the blepharoplast of the flagellates.

More recent studies with the electron microscope (van Iterson, 1947, 1953; Lofgren, 1948; Houwink, 1953) have shown that the origin of the flagella is intracellular but have not elucidated completely their mode of attachment. Van Iterson (1953) failed to find any evidence of a blepharoplast after autolysis of the cells, whereas Lofgren (1948) described a disk-like structure to which the flagellar strands were attached. Houwink (1953) observed a small hook at the base of each flagellar strand similar to those on the flagella of other bacteria. Blepharoplasts have, however, been observed in other bacterial groups, notably Proteus (Houwink \& van Iterson, 1950), Vibrio (van Iterson, 1953), Pseudomonas and Bacterium spp. (Bisset \& Hale, 1951). In these it was shown that each flagellum arose from a separate granule.

From their structure, as seen by the electron microscope, and from their behaviour, the flagella of large spirilla appear to be compound structures consisting of numerous slender fibrils which arise from a single blepharoplast and function as a single organ in a manner analogous to that of the simple, but much stouter flagellum of, for example, Vibrio spp. They are, thus, distinct from the multiple, separate flagella of other bacteria.

\section{METHODS}

To discover the general arrangement of their flagella, cells of Spirillum volutans, Sp. undula, Thiospira sp. and Rhodospirillum rubrum were examined and compared with Vibrio cholerae. The cells were suspended in distilled water, 
dried upon collodion or 'formvar' films, shadowed with metallic gold and examined with the electron microscope.

By this method, however, the mode of attachment of the flagella was not visible and a strain of Rhodospirillum rubrum was selected for further study. Cells from a $24 \mathrm{hr}$. culture were suspended in distilled water and incubated at $5^{\circ}$ for $18 \mathrm{hr}$. After this time, a large proportion of the cells appeared to be empty when stained with methylene blue. The bulk of the cells was then centrifuged off, and the supernatant was examined by the electron microscope.

\section{OBSERVATIONS}

Most of the spirilla examined possessed from ten to thirty or more flagellar fibres at one or both ends of the cell. These were usually arranged in one or more bundles making the total number difficult to count (Pl. 1, figs. 1, 2). Even when the flagellar fibrils were separate from one another, closer scrutiny showed that apparently single strands were often composed of more than one unit. The average diameter of each unit, as measured from electronmicrographs, is approximately $10 \mathrm{~m} \mu$., whereas that of the average flagellum of Vibrio and Pseudomonas spp. lies between 20 and $28 \mathrm{~m} \mu$.

In the electronmicrographs of the untreated cells, the flagella, usually from one to four in number, appeared to arise in bundles, but the cell contents were too opaque to the electron beam to show their mode of attachment ( $\mathrm{Pl}$. 1, fig. 1).

The strain of Rhodospirillum rubrum selected for further study possessed comparatively few flagella. After $18 \mathrm{hr}$. at $5^{\circ}$ a large proportion of the cells appeared to be partially or completely empty when viewed with the electron microscope. The flagella, however, were still attached to the cells and in many they appeared to arise from a single basal granule (Pl. 1, figs. 4-6).

In contrast, the cells of Vibrio cholerae which were examined possessed single, stout polar flagella. In several electron micrographs it was observed that the flagellum arose in the cell from a spherical structure about $100 \mathrm{~m} \mu$. in diameter similar to the basal granules seen in other groups of bacteria.

\section{DISCUSSION}

In the bacteria in which blepharoplasts have previously been demonstrated, and also as shown here in Vibrio cholerae, each flagellum appears to be attached to a separate basal granule or blepharoplast, whereas in spirilla the much smaller flagellar fibrils arise in bundles from the same blepharoplast, and constitute a single, complex organ.

This type of structure is intermediate between the typical bacterial flagellum and those of other types of Protista.

I wish to thank Miss C. M. F. Hale and Mr C. C. Newton for their assistance in making these electron micrographs. 
Journal of General Microbiology, Vol. 10, No. 2
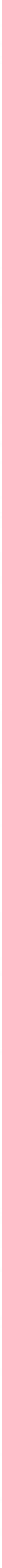

J. B. Grace-The flagella of spirilila. Plate 1 


\section{REFERENCES}

Bisset, K. A. \& Hale, C. M. F. (1951). The development of bacterial flagella in the germinating microcyst. J. gen. Microbiol. 5, 150.

Buder, J. (1915). Zur Kenntnis des Thiospirillum jenense und seiner Reaktionen auf Lichtreize. Jb. wiss. Bot. 56, 529.

Bütschli, O. (1902). Bemerkungen über Cyanophyceen und Bakteriaceen. Arch. Protistenk, 1, 41.

EHrenBerG, C. G. (1838). Die Infusionstierchen als vollkommene Organismen. Leipzig: Engelmann.

Ellis, D. (1902). Untersuchungen über Sarcina, Streptococcus und Spirillum. Zbl. Bakt. (1. Abt. Orig.), 33, 82.

Fuhrmann, F. (1909). Die Geisseln von Spirillum volutans. Zbl. Bakt. (2. Abt.), 25, 129.

Houwink, A. L. (1953). A macromolecular mono-layer in the cell wall of Spirillum species. Biochim. Biophys. Acta, 10, 360.

Houwink, A. L. \& Iterson, W. van. (1950). Electron-microscopical observations on bacterial cytology. II. A study of flagellation. Biochim. Biophys. Acta, 5, 10.

Iterson, W. van (1947). Some electron-microscopical observations on bacterial cytology. Biochim. Biophys. Acta, 1, 527.

ITERSON, W. vaN (1953). Some remarks on the Present State of our Knoweledge of Bacterial Flagellation. Bacterial Cytology, p. 24. Symp. VI. Cong. Int. Microbiol. Oxford: Blackwell.

Lofgren, R. (1948). The structure of Spirillum rubrum. Bact. Proc. 1, 15.

PrJPer, A. (1949). The flagella of Spirillum volutans. J. Bact. 57, 111.

Reichert, K. (1909). Utber die Sichtbarmachung der Geisseln und der Geisselbewegung der Bakterien. Zbl. Bakt. (1. Abt. Orig.), 51, 14.

YuASA, A. (1936). Cytomorphological study of Rhodospirillum longum Hama. Bot. Mag., Tokyo, 50, 93.

\section{EXPLANATION OF PLATE}

Fig. 1. Thiospira sp. showing three bundles of fibrils emerging from the cell and becoming united into a single strand. Electron micrograph, gold shadowed, $\times 10,000$.

Fig. 2. Thiospira sp. showing flagellar fibrils arranged in a single bundle. A similar appearance to that observed in living cells. Electron micrograph, gold shadowed, $\times 5000$.

Fig. 3. Vibrio cholerae showing a single, thick flagellum attached inside the cell to a basal granule. Electron micrograph, gold shadowed, $\times 25,000$.

Figs. 4-6. Rhodospirillum rubrum autolysed cells showing the flagellar fibrils attached to a single basal structure. Electron micrographs, gold shadowed, $\times 25,000$. 